\title{
Antibiotic Susceptibility of Staphylococcus Aureus Isolated from Skin Lesions in Children. A Retrospective Analysis from a Tertiary Care Italian Pediatric Hospital
}

\author{
Marilea Lezzi \\ Roberto Bandettini \\ Istituto Giannina Gaslini \\ Elisabetta Ugolotti \\ Istituto Giannina Gaslini \\ Carolina Saffioti \\ Istituto Giannina Gaslini \\ Alessio Mesini \\ Istituto Giannina Gaslini \\ Carlotta Pastorino \\ Istituto Giannina Gaslini
}

Universita degli Studi di Genova Dipartimento di Economia

Francesca Manunza

Istituto Giannina Gaslini

Marta Ferretti

Istituto Giannina Gaslini

Giacomo Brisca

Istituto Giannina Gaslini

Elio Castagnola ( $\nabla$ eliocastagnola@gaslini.org )

Istituto Giannina Gaslini https://orcid.org/0000-0002-5336-8429

\section{Research}

Keywords: Staphylococcus aureus, antibiotic resistance, skin infection, pediatrics, topical antibiotics

Posted Date: September 17th, 2020

DOI: https://doi.org/10.21203/rs.3.rs-65376/v1

License: (c) (i) This work is licensed under a Creative Commons Attribution 4.0 International License. Read Full License

Version of Record: A version of this preprint was published at Journal of Chemotherapy on December 4th, 2020. See the published version at https://doi.org/10.1080/1120009X.2020.1852832. 


\section{Abstract}

Background: knowledge on antibiotic susceptibility of S.aureus strains isolated from skin lesions in pediatric Italian patients is limited.

Methods: retrospective analysis of antibiotic susceptibility of S.aureus strains isolated from skin infections observed from January 2013 to June 2019 at the IRCCS Istituto Giannina Gaslini, Genoa - Italy

Results: a total of 1833 strains were analyzed. Methicillin resistance was more frequent in cultures from outpatients than from inpatients $(18 \%$ vs. $14 \%, p=0.04)$ as well as resistance to cotrimoxazole $(8 \%$ vs. $4.1 \%, p<0.001)$ Resistance to ampicillin was $99 \%$ in both groups, while to clindamycin it was $11 \%$ and $14 \%$, respectively. Among topical antibiotics fusidic acid showed the better resistance profile (3\%).

Conclusions: the proportion of antibiotic resistance in S.aureus skin infections in Italian children is not negligible. This could represent a problem, especially for orally administered drugs.

\section{Background}

Staphylococcus aureus is the most common cause of skin infections with an increasing prevalence of antibiotic resistance and consequent restriction of treatment options. ${ }^{1}$

To our knowledge, data about resistance profile of $S$. aureus in skin lesions in children are overall poor, mostly in Italy.

We evaluated antibiotic susceptibility of $S$. aureus isolated from cutaneous lesions in patients followed up at a tertiary care Italian pediatric hospital.

\section{Materials And Methods}

The IRCCS Istituto Giannina Gaslini - Genoa is a tertiary care children's hospital in Northern Italy serving as local pediatric hospital for the Genoa area but representing also a referral hospital nationwide and for many foreign countries.

All S. aureus strains isolated from skin lesions in patients < 18 years from January 2013 to June 2019 were extracted from the Laboratory of Microbiology database. In case of multiple isolations of the same strain in a single patient only the first isolate was considered. Subsequently data were anonymized, according to Gaslini Institute data protection policy based on European Union Data Protection Rules. The need for informed consent was waived given the retrospective nature of the study and the anonymization of the data.

S. aureus identification was confirmed by MALDI-TOF technology (Vitek MS, BioMerieux, France), according to the manufacturer's instructions. For each strain the susceptibility to the following antibiotics (Vitek MS, BioMerieux, France) was recorded: ampicillin, methicillin, ciprofloxacin, clindamycin, cotrimoxazole, fusidic acid, mupirocin, gentamicin. These last 3 drugs were included since in Italy they have topical formulations and are frequently sold as out of the counter drugs. The interpretation of the results was based on The European Committee on Antimicrobial Susceptibility Testing (EUCAST) breakpoint criteria. ${ }^{2}$

Since the study was based on a laboratory database no information was available on demographic and clinical data, but only ward of admission was available, that was used to classify patients as outpatients if sampled in 
Emergency Department, Dermatology Unit and Infectious Diseases Unit, considering the hospital protocols for hospital admission. Patients from all other wards were considered inpatients.

\section{Statistical analysis}

Data were reported as proportions with 95\% Confidence Interval $(95 \% \mathrm{Cl})$. Differences among proportions were evaluated by chi-square test with Yates correction or Fisher's exact test, when appropriate. A P value $<0.05$ was considered as statistically significant. Analysis was performed by means of the web platform Social Science Statistics. https://www.socscistatistics.com/

\section{Results}

During the study period a total of 1833 S.aureus strains were extracted, 430 (23.4\%) classified as from out-patients. Table 1 reports on antibiotic susceptibility among isolated strains, stratified as from outpatients or inpatients. The proportion of methicillin-resistant S.aureus (MRSA) was significantly higher in outpatients (18\% vs. 14\%, $p=0.04)$. Ampicillin resistance was $99 \%$ in both subsets and also resistance to clindamycin and ciprofloxacin was similar in the 2 groups. On the contrary, resistance to cotrimoxazole was significantly higher in outpatients $(p<0.001$, chisquare test). 
Table 1

Proportions of resistance in 1833 S.aureus strain isolated from skin lesions.

\begin{tabular}{|c|c|c|c|c|c|c|c|c|c|}
\hline & \multicolumn{3}{|c|}{ Outpatients $n=430$} & \multicolumn{3}{|c|}{ Inpatients $n=1403$} & \multicolumn{3}{|c|}{ Total $n=1833$} \\
\hline & $\begin{array}{l}\text { Tested } \\
\text { (n) }\end{array}$ & $\begin{array}{l}\text { Resistant } \\
\text { strains } \\
\text { (n) }\end{array}$ & $\begin{array}{l}\text { Not } \\
\text { tested } \\
\text { (n) }\end{array}$ & $\begin{array}{l}\text { Tested } \\
\text { (n) }\end{array}$ & $\begin{array}{l}\text { Resistant } \\
\text { strains } \\
\text { (n) }\end{array}$ & $\begin{array}{l}\text { Not } \\
\text { tested } \\
\text { (n) }\end{array}$ & $\begin{array}{l}\text { Tested } \\
\text { (n) }\end{array}$ & $\begin{array}{l}\text { Resistant } \\
\text { strains } \\
\text { (n) }\end{array}$ & $\begin{array}{l}\text { Not } \\
\text { tested } \\
\text { (n) }\end{array}$ \\
\hline \multirow[t]{2}{*}{ Methicillin } & 420 & 77 & 10 & 1382 & 198 & 21 & 1802 & 275 & 31 \\
\hline & & $\begin{array}{l}(18 \\
95 \% \mathrm{Cl} \\
15-22)\end{array}$ & $\begin{array}{l}(2.3, \\
95 \% \mathrm{Cl} \\
1-4)\end{array}$ & & $\begin{array}{l}(14 \\
95 \% \mathrm{Cl} \\
12-16)\end{array}$ & $\begin{array}{l}(1.5, \\
95 \% \mathrm{Cl} \\
1-2)\end{array}$ & & $\begin{array}{l}(15 \\
95 \% \mathrm{Cl} \\
13-17)\end{array}$ & $\begin{array}{l}(1.7 \\
95 \% \mathrm{Cl} \\
1-2)\end{array}$ \\
\hline \multirow[t]{2}{*}{ Ampicillin } & 191 & 189 & 239 & 697 & 692 & 706 & 888 & 881 & 945 \\
\hline & & $\begin{array}{l}(99 \\
95 \% \mathrm{Cl} \\
98-100)\end{array}$ & $\begin{array}{l}(56, \\
95 \% \mathrm{Cl} \\
51- \\
60)\end{array}$ & & $\begin{array}{l}(99 \\
95 \% \mathrm{Cl} \\
98-100)\end{array}$ & $\begin{array}{l}(50, \\
95 \% \mathrm{Cl} \\
48- \\
53)\end{array}$ & & $\begin{array}{l}(99 \\
95 \% C \\
99-100)\end{array}$ & $\begin{array}{l}(52 \\
95 \% \mathrm{Cl} \\
50- \\
54)\end{array}$ \\
\hline \multirow[t]{2}{*}{ Clindamycin } & 413 & 45 & 17 & 1331 & 187 & 72 & 1744 & 532 & 89 \\
\hline & & $\begin{array}{l}(11 \\
95 \% \mathrm{Cl} \\
8-14)\end{array}$ & $\begin{array}{l}(3.9, \\
95 \% \mathrm{Cl} \\
2-6)\end{array}$ & & $\begin{array}{l}(14 \\
95 \% \mathrm{Cl} \\
12-16)\end{array}$ & $\begin{array}{l}(5, \\
95 \% \mathrm{Cl} \\
4-6)\end{array}$ & & $\begin{array}{l}(30 \\
95 \% \mathrm{Cl} \\
28-32)\end{array}$ & $\begin{array}{l}4.9 \\
95 \% \mathrm{Cl} \\
4-6)\end{array}$ \\
\hline \multirow[t]{2}{*}{ Cotrimoxazole } & 427 & 35 & 3 & 1401 & 58 & 2 & 1828 & 93 & 5 \\
\hline & & $\begin{array}{l}(8,95 \% \mathrm{Cl} \\
6-11)\end{array}$ & $\begin{array}{l}(0.7 \\
95 \% \mathrm{Cl} \\
0-1)\end{array}$ & & $\begin{array}{l}(4.1 \\
95 \% \mathrm{Cl} \\
3-5)\end{array}$ & $\begin{array}{l}(0.1 \\
95 \% \mathrm{Cl} \\
0-0)\end{array}$ & & $\begin{array}{l}(5,95 \% \mathrm{Cl} \\
4-6)\end{array}$ & $\begin{array}{l}(0.3 \\
(95 \% \mathrm{Cl} \\
0-1)\end{array}$ \\
\hline \multirow[t]{2}{*}{ Ciprofloxacin } & 387 & 23 & 43 & 1228 & 92 & 175 & 1615 & 115 & 218 \\
\hline & & $\begin{array}{l}(6,95 \% \mathrm{Cl} \\
4-8)\end{array}$ & $\begin{array}{l}(10, \\
95 \% \mathrm{Cl} \\
7-13)\end{array}$ & & $\begin{array}{l}(7,95 \% \mathrm{Cl} \\
6-9)\end{array}$ & $\begin{array}{l}(12, \\
95 \% \mathrm{Cl} \\
11- \\
14)\end{array}$ & & $\begin{array}{l}(7,95 \% \mathrm{Cl} \\
6-8)\end{array}$ & $\begin{array}{l}(12, \\
95 \% \mathrm{Cl} \\
11- \\
13)\end{array}$ \\
\hline \multirow[t]{2}{*}{ Gentamicin } & 427 & 39 & 3 & 1398 & 166 & 5 & 1825 & 205 & 8 \\
\hline & & $\begin{array}{l}(9,95 \% \mathrm{Cl} \\
6-12)\end{array}$ & $\begin{array}{l}(0.7 \\
95 \% \mathrm{Cl} \\
0-1)\end{array}$ & & $\begin{array}{l}(12, \\
95 \% \mathrm{Cl} \\
10-14)\end{array}$ & $\begin{array}{l}(0.5 \\
95 \% \mathrm{Cl} \\
0-1)\end{array}$ & & $\begin{array}{l}(11, \\
95 \% \mathrm{Cl} \\
10-12)\end{array}$ & $\begin{array}{l}(0.4 \\
95 \% \mathrm{Cl} \\
0-1)\end{array}$ \\
\hline \multirow[t]{2}{*}{ Fusidic acid } & 281 & 10 & 149 & 874 & 28 & 529 & 1155 & 38 & 678 \\
\hline & & $\begin{array}{l}(3.6, \\
95 \% \mathrm{Cl} \\
1-6)\end{array}$ & $\begin{array}{l}(35 \\
95 \% \mathrm{Cl} \\
30- \\
39)\end{array}$ & & $\begin{array}{l}(3.2, \\
95 \% \mathrm{Cl} \\
2-4)\end{array}$ & $\begin{array}{l}(38, \\
95 \% \mathrm{Cl} \\
35- \\
40)\end{array}$ & & $\begin{array}{l}(3.3 \\
95 \% \mathrm{Cl} \\
2-4)\end{array}$ & $\begin{array}{l}(37 \\
95 \% \mathrm{Cl} \\
35- \\
39)\end{array}$ \\
\hline \multirow[t]{2}{*}{ Mupirocin } & 130 & 2 & 300 & 425 & 27 & 978 & 555 & 29 & 1278 \\
\hline & & $\begin{array}{l}(1.5, \\
95 \% \mathrm{Cl}-1- \\
4)\end{array}$ & $\begin{array}{l}(70, \\
95 \% \mathrm{Cl} \\
65- \\
74)\end{array}$ & & $\begin{array}{l}(6,95 \% \mathrm{Cl} \\
4-9)\end{array}$ & $\begin{array}{l}(70, \\
95 \% \mathrm{Cl} \\
67- \\
72)\end{array}$ & & $\begin{array}{l}(5,95 \% \mathrm{Cl} \\
3-7)\end{array}$ & $\begin{array}{l}(70, \\
95 \% \mathrm{Cl} \\
68- \\
72)\end{array}$ \\
\hline
\end{tabular}


As for drugs with topical formulations, resistance to gentamycin and fusidic acid was similar in in- and outpatients, while for inpatients resistance to mupirocin was significantly higher $(p=0.0309$, chi-square test), even if many strains were not tested for mupirocin susceptibility (70\% in both groups).

\section{Discussion}

In this study we describe the profile of antimicrobial susceptibility of $S$. aureus strains isolated from cutaneous lesions in a pediatric tertiary care center in Italy. To our knowledge, no other Italian data on this topic are available.

The first observation we can drive is that even if the prevalence of MRSA we observed was lower than in other pediatric studies from other countries $3,4,5$, the proportion this pathogen on skin lesions was significantly higher in outpatients compared with inpatients. However, since $95 \% \mathrm{Cl}$ of the proportions are imbricated it is probable that this difference is not clinically relevant but represents only a statistical effect. ${ }^{6}$

Since no other pediatric Italian data are available we can not make any national comparison, but it must be noted that European data (including also adults) report a MRSA prevalence of $15.1 \%$, with a North (0\%) to South (29\%) increasing gradient ${ }^{7}$, that is consistent with our observations.

A recent Italian consensus on the treatment of skin infections in pediatrics ${ }^{8}$ indicated clindamycin for first line treatment in communities where proportions of MRSA is $>10 \%$ if clindamycin resistance is $<10 \%$. Considering our epidemiology clindamycin ( $11 \%$ in out- and $14 \%$ in inpatients resistant strains) did not meet these criteria and could not represent a possible choice for empirical therapy before susceptibility tests availability. We do not know if this observation can be generalized to other Italian regions, but this observation should represent a warning. In spite of the significantly higher proportion of strains resistant to cotrimoxazole in outpatients ( $8 \%$ vs. $4.1 \%)$, as already described $^{9}$, in our study resistance to cotrimoxazole was lower than the $10 \%$ threshold proposed for other drugs to be used for first line therapy of skin lesions ${ }^{8}$ and therefore it could represent an acceptable first choice, pending susceptibility tests. The generally lower proportion of resistant strains in inpatients could seem a paradox. However, IGG has a strict policy of antibiotics use and effective patients' isolation procedure in presence of resistant strains ${ }^{10}$ that could at least partially explain this observation.

The use of topical antibiotics has been associated with selection of resistant strains. ${ }^{11}$ In our study data on resistance to mupirocin could be poorly reliable because of the high proportion (70\%) of untested strains; Fusidic acid showed a very low proportion of resistance (about $3 \%$ of resistance) but also in this case near $1 / 3$ of strains were not tested. Finally, topical gentamycin is a highly used over the counter topical antibiotic in Italy, and indeed the resistance is not negligible (9-12\%). Our data suggest that fusidic acid is the better topical choice ${ }^{8}$, at least in our epidemiological condition.

The main limitation of this study is the lack of clinical data, due to fact that it is derived from a laboratory database. Despite this, it gives information about an important item such as antimicrobial resistance in pediatric staphylococcal skin infections in a geographic area and clinical field where epidemiological data are lacking.

\section{Conclusions}

S.aureus strains isolated from skin infections in Italian children shows a high proportion of resistance, especially in outpatients (18\%), is high also for clindamycin (11\%), while is not negligible for cotrimoxazole ( $8 \%)$. This could represent a problem for initial antibacterial therapy in the outpatient setting pending cultures results. As an apparent 
paradox, resistance proportions are lower in cultures from inpatients. This could be due to a strict control of antibiotic administration and adherence to isolation procedures, that represent cornerstones to reduce the spread of antibiotic resistant bacteria within hospitals.

\section{Declarations}

Ethics approval and consent to participate: Not applicable since retrospective analysis of anonymous laboratory data

Consent for publication: Not applicable.

Availability of data and materials: All data generated or analysed during this study are included in this published article.

Competing interests: The authors declare that they have no competing interests.

Funding: None.

Authors' contribution

Marilea Lezzi Data collection and analysis, $1^{\text {st }}$ paper draft, final version approval

Roberto Bandettini Study design, data collection, final version approval

Elisabetta Ugolotti Data collection, final version approval

Carolina Saffioti Data and results analysis and comments, final version approval

Alessio Mesini Data and results analysis and comments, final version approval

Carlotta Pastorino Data and results analysis and comments, final version approval

Francesca Data and results analysis and comments, final version approval

Manunza

Marta Ferretti Data and results analysis and comments, final version approval

Giacomo Brisca Data and results analysis and comments, final version approval

Elio Castagnola Study design, data and results analysis and comments, paper review, final version approval

\section{References}

1. Foster TJ. Antibiotic resistance in Staphylococcus aureus. Current status and future prospects. FEMS Microbiol Rev. 2017;41:430-49.

2. The European Committee on Antimicrobial Susceptibility Testing. Breakpoint tables for interpretation of MICs and zone diameters, version 10.0, 2020. http://www.eucast.org/clinical_breakpoints/.

3. Ortega-Loayza AG, Diamantis SA, Gilligan P, Morrell DS. Characterization of Staphylococcus aureus cutaneous infections in a pediatric dermatology tertiary health care outpatient facility. J Am Acad Dermatol. 2010;62:80411. http://dx.doi.org/10.1016/j.jaad.2009.07.030. 
4. Herold BC, Immergluck LC, Maranan MC, Lauderdale DS, Gaskin RE, Boyle-Vavra S, Leitch CD, Daum RS. Community-acquired methicillin-resistant Staphylococcus aureus in children with no identified predisposing risk. JAMA. 1998;279:593-8. doi:10.1001/jama.279.8.593.

5. Castaño-Jaramillo LM, Beltrán-Arroyave C, Santander-Peláez LC, Vélez-Escobar AM, Garcés-Samudio CG, Trujillo-Honeysberg M. Características clínicas y microbiológicas de las infecciones de piel y tejidos blandos por Staphylococcus aureus en niños de un hospital en Medellín durante los años 2013 a 2015 [Clinical and microbiological characteristics of skin and soft tissue infections caused by Staphylococcus aureus in children in a hospital in Medellin from 2013 to 2015]. Rev Chilena Infectol. 2017;34:487-90. doi:10.4067/S071610182017000500487.

6. Braitman LE. Confidence intervals assess both clinical significance and statistical significance. Ann Intern Med. 1991;114:515-7. doi:10.7326/0003-4819-114-6-515.

7. Bouchiat C, Curtis S, Spiliopoulou I, Bes M, Cocuzza C, Codita I, Dupieux C, Giormezis N, Kearns A, Laurent F, Molinos S, Musumeci R, Prat C, Saadatian-Elahi M, Tacconelli E, Tristan A, Schulte B, Vandenesch F. ESCMID Study Group on Staphylococci and Staphylococcal Infections (ESGS). MRSA infections among patients in the emergency department: a European multicentre study. J Antimicrob Chemother. 2017;72:372-5. doi:10.1093/jac/dkw431.

8. 10.1016/j.clinthera.2019.01.010 Galli L, Venturini E, Bassi A, Gattinara GC, Chiappini E, Defilippi C, Diociaiuti A, Esposito S, Garazzino S, Giannattasio A, Krzysztofiak A, Latorre S, Lo Vecchio A, Marchisio P, Montagnani C, Nicolini G, Novelli A, Rossolini GM, Tersigni C, Villani A, El Hachem M, Neri I; Italian Pediatric Infectious Diseases Society; Italian Pediatric Dermatology Society. Common Community-acquired Bacterial Skin and Soft-tissue Infections in Children: an Intersociety Consensus on Impetigo, Abscess, and Cellulitis Treatment. Clin Ther. 2019;41:532 51.e17. doi: 10.1016/j.clinthera.2019.01.010.

9. Khamash DF, Voskertchian A, Tamma PD, Akinboyo IC, Carroll KC, Milstone AM. Increasing Clindamycin and Trimethoprim-Sulfamethoxazole Resistance in Pediatric Staphylococcus aureus Infections. J Pediatric Infect Dis Soc. 2019;8:351-3. doi:10.1093/jpids/piy062.

10. Castagnola E, Tatarelli P, Mesini A, Baldelli I, La Masa D, Biassoni R, Bandettini R. Epidemiology of carbapenemase-producing Enterobacteriaceae in a pediatric hospital in a country with high endemicity. J Infect Public Health. 2019;12:270-4. doi:10.1016/j.jiph.2018.11.003.

11. Carter GP, Schultz MB, Baines SL, Gonçalves da Silva A, Heffernan H, Tiong A, Pham PH, Monk IR, Stinear TP, Howden BP, Williamson DA. Topical Antibiotic Use Coselects for the Carriage of Mobile Genetic Elements Conferring Resistance to Unrelated Antimicrobials in Staphylococcus aureus. Antimicrob Agents Chemother. 2018;62:e02000-17. doi:10.1128/AAC.02000-17. 